удК 347.627

DOI https://doi.org/10.32837/yuv.v0i5.2247

В. Плєва,

кандидат юридичних наук, доцент, професор кафедри цивільно-правових дисциплін

Національної академії внутрішніх справ

B. Мазур,

кандидат юридичних наук, доцент, доцент кафедри цивільно-правових дисциплін

Національної академії внутрішніх справ

\title{
КВЕСТІЇ ЗУПИНЕННЯ ПРОВАДЖЕННЯ У СПРАВІ ПРО РОЗІРВАННЯ ШЛЮБУ ТА НАДАННЯ СТРОКУ ДЛЯ ПРИМИРЕННЯ ПОДРУЖЖЮ
}

В Україні довготривало і постійно триває реформування законодавства до певних стандартів та узгодження 3 повсякденними реаліями життя, це не оминуло й цивільно-процесуальну сферу. Як відомо, у зв'язку 3 реформуванням цивільно-процесуального законодавства України та внесенням змін, зокрема шляхом прийняття Закону України від 03 жовтня 2017 року «Про внесення змін до Господарського процесуального кодексу України, Цивільного процесуального кодексу України, Кодексу адміністративного судочинства України та інших законодавчих актів» до Цивільного процесуального кодексу України було введено в дію низку новел, у тому числі щодо зупинення провадження у справі про розірвання шлюбу й надання строку для примирення подружжю. Хоч і запроваджено зміни до вказаних вище правовідносин і викладено зміст норм дещо інакше, це не запобігло наразі плутанині у тлумаченні, розумінні і застосуванні норм законодавства щодо зупинення провадження у справі про розірвання шлюбу і надання строку для примирення подружжю. Для того, щоб у майбутньому не виникало квестій, спірних питань, колізій у судовій практиці щодо вказаної проблематики, вважаємо, що натепер вказана проблематика актуальна і необхідно зробити більш детальне, повне та всебічне дослідження та аналіз норм, які стосуються зупинення провадження у справі про розірвання шлюбу та надання строку для примирення подружжю.

У сучасній науковій літературі комплексні дослідження щодо зупинення провадження у справі про розірвання шлюбу та надання строку для примирення подружжю не проводилися. Дослідженням питань зупинення провадження у справі присвячені роботи таких науковців: Я.П. Зейкан, О.М. Трач, М.Й. Штефан, С.Я. Фурса та інших вчених.

Спочатку все здається простим: є п. 4 ч. 1 ст. 251 Цивільного процесуального кодексу України (далі - ЦПК України) [1], у якій вказується про обов'язок суду зупинити провадження у разі надання сторонам у справі про розірвання шлюбу строку для примирення. Але чомусь законодавець вирішив за необхідне викласти схожу позицію і в ч. 7 ст. ст. 240 ЦПК України «Відкладення розгляду справи або перерва 
в судовому засіданні» в такому трактуванні: «У справі про розірвання шлюбу суд може зупинити розгляд справи i призначити подружжю строк для примирення, який не може перевищувати шести місяців» [1]. Виникає питання, навіщо все ж таки законотворець в одній статі вказує на обов'язок суду зупинити провадження, а в іншій, яка стосується відкладення розгляду справи - на право суду зупинити провадження у справі. Оскільки не кожну справу можна розглянути в одному судовому засіданні та в одному безперервному процесі, то виникає потреба тимчасово зупинити провадження у справі, відкласти розгляд справи або оголосити перерву в судовому засіданні, а цивільно-процесуальне законодавство дефініцій вказаних понять не розкриває. Вважаємо доречним з'ясувати поняття таких інститутів цивільно-процесуального та господарського-процесуального законодавства, як відкладення розгляду справи та зупинення провадження у справі на науково-теоретичному рівні.

На думку Я.П., Зейкана зупинення провадження у справі - це тимчасова і повна зупинка всіх процесуальних дій у справі, у зв'язку 3 настанням передбачених у законі обставин, які перешкоджають подальшому судочинству. У цьому випадку, справа хоч і не закінчена, але повністю знімається 3 провадження [2, с. 315].

На думку М.Й. Штефана, зупинення провадження у справі - це тимчасове, на невизначений строк, припинення процесуальних дій щодо розгляду справи, спричинене обставинами, які унеможливлюють подальший розвиток процесу [3, с. 388].

С.Я. Фурса зупиненням провадження у справі називає тимчасове припинення провадження у справі на точно не визначений строк, який виникає 3 настанням певних об'єктивних обставин, точно визначених у законі, за наявності яких суд не може продовжити розгляд справи [4, с. 651].

У науково-практичному коментарі до Господарського процесуального кодексу України вказується, що зупинення провадження у справі - тимчасове й повне припинення всіх процесуальних дій у справі, що викликане настанням зазначених у законі причин, що перешкоджають подальшому руху процесу і щодо яких невідомо, коли вони можуть бути усунені [5, с. 438].

Інші науковці вважають, що зупинення провадження у справі - окремий правовий інститут цивільного процесуального права, метою якого $€$ перенесення судового розгляду справи на інший, більш пізній термін, за визначених у законі підстав [6, с. 432].

На думку О.М. Трач, зупинення провадження у справі - це оформлене ухвалою суду тимчасове припинення вчинення судом процесуальних дій, за винятком забезпечення доказів, забезпечення позову, під час підготовки справи до судового розгляду, судового розгляду, яке викликане наявністю визначених у законі обставин, що перешкоджають подальшому розгляду цивільної справи і щодо яких неможливо передбачити конкретний момент їх усунення [7, с. 48].

3 усіх вказаних вище понять випливає, що однією 3 основних ознак, яка характеризує і виокремлює зупинення провадження у справі від інших інститутів тимчасового припинення розгляду справи, є неможливість встановити та визначити тривалість дії обставин, що стали підставами для постановлення суддею ухвали про зупинення провадження.

3 характеристикою норм Цивільного процесуального кодексу України можна інститут зупинення провадження у справі поділити, залежно від настання певних обставин, на такі види, як обов'язкові (ст. 251 ЦПК України) та факультативні (ст. 252 ЦПК України). 
Що ж стосується відкладення розгляду справи, то це перенесення розгляду справи по суті з призначенням точної дати та місця нового судового засідання [6, с. 430].

Відкладення розгляду справи - це перенесення засідання суду на інший час у зв'язку з виявленням обставин, що перешкоджають вирішенню справи по суті в конкретному засіданні [8].

Деякі вчені-процесуалісти зазначають, що відкладення розгляду справи полягає в перенесенні засідання на інший строк із тим, щоб забезпечити необхідні умови розв'язання спору. По своїй суті це організаційні заходи суду щодо забезпечення принципу всебічного, повного та об'єктивного розгляду позовних вимог [9, с. 154].

Як бачимо, у всіх викладених вище поняттях основною особливістю відкладення розгляду справи $€$ те, що за відкладення iï розгляду суд вказує строк, протягом якого повинні бути усунені перешкоди для подальшого розгляду справи, і водночас призначає місце, дату та час наступного судового засідання.

Зупинення провадження у справі, на відмінну від відкладення іiі розгляду, здійснюється на невизначений строк - на строк, протягом якого існуватимуть обставини, що стали підставою для такого зупинення [6, с. 432].

Вважаємо за доцільне виокремити спільні та відмінні риси інститутів зупинення провадження у справ та відкладення розгляду справи, які можуть допомогти в майбутньому запобігти квестіям у науково-теоретичному та практичному розумінні цих двох інститутів.

Щодо спільних рис, то можна вказати на такі:

1) це інститути цивільно-процесуального та господарського-процесуального законодавства;

2) обставини, за яких зупиняється провадження і відкладається розгляд справи врегульовані процесуальним законом;
3) у двох випадках суд постановляє ухвалу про тимчасову перерву в провадженні;

4) передбачається перенесення судового засідання в справі на інший час;

5) тощо.

Що ж стосується відмінностей, то слід зазначити такі риси, як:

1) у разі відкладення розгляду справи суд вказує місце, день та час нового судового засідання (ч. 3 ст. 240 ЦПК України, ч. 3 ст. 216 Господарського процесуального кодексу України (далі - ГПК України) [10]); за умови зупинення провадження у справі строк не зазначається;

2) у разі зупинення - провадження у справі продовжується зі стадії, на якій його було зупинене (ч. 3 ст. 254 ЦПК України, ч. 3 ст. 230 ГПК України); у випадку відкладення - суд продовжує провадження у справі зі стадії, на якій розгляд справи було відкладено. У випадку відкладення розгляду справи під час іiі розгляду по суті суд може почати розгляд справи по суті спочатку (ч. 5 ст. 240 ЦПК України, ч. 5 ст. 216 ГПК України);

3) зупинення провадження у справі зупиняє перебіг процесуальних строків (ч. 1 ст. 125 ЦПК України; ч. 1 ст. 117 ГПК України), і продовжується 3 дня поновлення провадження у справі (ч. 2 ст. 125, ч. 2 ст. 254 ЦПК України, ч. 2 ст. 117 , ч. 2 ст. 230 ГПК України); за відкладення розгляду справи перебіг процесуальних строків продовжується;

4) у випадках, передбачених законом, суд повинен дотримуватися обставин щодо обов'язкового зупинення провадження у справі (ст. 251 ЦПК України, ст. 227 ГПК України), а також існують підстави, коли суд має право на зупинення провадження (ст. 252 ЦПК України, ст. 227 ГПК України). Якщо мова йде про відкладення розгляду справи, то законом такі підстави для обов'язкового та факультативного відкладення не передбачені; 
5) передбачені законом обставини для зупинення провадження у справі $€$ вичерпними, а щодо відкладення розгляду справи, то законом вичерпний перелік таких обставин не встановлюється і вони підлягають додатковому тлумаченню (п. 3 ч. 2 ст. 198 ЦПК України, п. 3 ч. 2 ст. 183 ГПК України). Щодо інших випадків відкладення розгляду справи, можна зазначити такі, як пред'явлення відповідачем зустрічного позову, необхідність витребувати нові докази тощо;

6) також є відмінність щодо поновлення провадження: у разі зупинення провадження - провадження у справі поновлюється за клопотанням учасників справи або за ініціативою суду не пізніше десяти днів з дня отримання судом повідомлення про усунення обставин, що викликали його зупинення (ч. 1 ст. 254 ЦПК України, ч. 1 ст. 230 ГПК України); за відкладення розгляду справи - суд відкладає розгляд справи в судовому засіданні в межах встановленого строку на загальних підставах (ч. 2 ст. 223 ЦПК України, ч. 2 ст. 202 ГПК України);

7) ухвали про зупинення провадження у справі можуть бути оскаржені в апеляційному порядку окремо від рішення суду першої інстанції (п. 14 ч. 1 ст. 353 ЦПК України, п. 12 ч. 1 ст. 255 ГПК України); на ухвали про відкладення розгляду справи таке правило законодавством не передбачається;

8) та інші відмінні риси.

Виокремивши спільні та відмінні риси інститутів зупинення провадження у справі від відкладення розгляду справи, можемо зауважити, що тимчасове припинення провадження у справі про розірвання шлюбу i надання строку для примирення подружжю однозначно віднести до якогось конкретного інституту не можна, тому вважаємо, що для більш повного та всебічного дослідження проблематики статті необхідно роз- глянути та проаналізувати судову практику.

Оскільки проаналізувати всю судову практику в одній статті неможливо, для прикладу опрацюємо такі ухвали: 1) Ухвала про зупинення провадження у справі та надання строку для примирення від 5 серпня 2019 року Справа № $523 / 7954 / 19$ Провадження № 2/523/3375/19 [11]; 2) Ухвала про зупинення провадження у справі та надання строку для примирення від 7 жовтня 2019 року Справа № $477 / 2148 / 19$ Провадження № $2 / 477 / 905 / 19$ [12]; 3) Ухвала про зупинення провадження у справі та надання строку для примирення від 26 травня 2021 року Справа № $477 / 243 / 21$ Провадження № $2 / 477 / 464 / 21$ [13].

Для всіх трьох ухвал спільним є те, що суд зупиняючи розгляд справи про розірвання шлюбу i надання строку для примирення подружжю, вказує місце, день та час нового судового засідання, що $€$ характерною особливістю не для зупинення провадження у справі, а для відкладення розгляду справи. Але з цього правила в ЦПК України передбачено виняток, а також строк, на який зупиняється провадження у справі для примирення подружжя: такий строк визначає суддя (згідно п. 3 ч. 1 ст. 253 ЦПК України).

Відповідно до ч. 1 ст. 111 Сімейного кодексу України, «суд вживає заходів щодо примирення подружжя, якщо це не суперечить моральним засадам суспільства» [14]. Щодо цієї норми в Постанові Пленуму Верховного суду України від 21 грудня 2007 року № 11 «Про практику застосування судами законодавства при розгляді справ про право на шлюб, розірвання шлюбу, визнання його недійсним та поділ спільного майна подружжя» в п. 2 ч. 10 вказується, що передбачене ч. 1 ст. 111 Сімейного кодексу України вжиття судом заходів щодо примирення подружжя 
застосовується у випадку відсутності згоди одного з них на розірвання шлюбу за ініціативою однієі зі сторін або суду у формі відкладення розгляду справи слуханням та надання сторонам строку на примирення. Судам слід використовувати надану законом можливість відкласти розгляд справи для примирення подружжя, особливо за наявності неповнолітніх дітей [15]. Хоча норми Цивільного процесуального кодексу України зазнали змін, але, як бачимо, в Постанові Пленуму Верховного суду України [15] мова все ж таки йде про відкладення розгляду справи.

Також у всіх трьох постановлених ухвалах вказується, що ухвала про зупинення провадження у справі може бути оскаржена до апеляційного суду, крім тієї частини, яка стосується надання сторонам строку на примирення і вона оскарженню не підлягає. А як нам відомо із проаналізованого вище матеріалу, ухвали про зупинення провадження у справі можуть бути оскаржені в апеляційному порядку окремо від рішення суду першої інстанції відповідно до п. 14 ч. 1 ст. 353 ЦПК України.

Серед квестій хотілося б виокремити та з'ясувати таку норму, передбачену ЦПК України, як обов'язок суду зупинити провадження у справі й надати сторонам у справі про розірвання шлюбу строку для примирення. Цікавим і незрозумілим є саме те, що сторонам надається строк для примирення. Але ж, відповідно до ч. 3 ст. 293 ЦПК України категорії справ про розірвання шлюбу можуть розглядатися і в окремому провадженні, а там учасниками справи є заявники та інші зацікавлені особи (ч. 3 ст. 42 ЦПК Украіни). Тоді виходить, що суд зобов'язаний надати строк для примирення у позовному провадженні і посилатися на п. 4 ч. 1 ст. 251 ЦПК Україн і може не зупинити / має право зупинити в окремому провадженні і керуватися ч. 7 ст. 240 ЦПК Укра- їни. Щодо окремого провадження, то відповідно до ч. 8 Постанови Пленуму Верховного суду Украіни від 21 грудня 2007 № 11 «Про практику застосування судами законодавства при розгляді справ про право на шлюб, розірвання шлюбу, визнання його недійсним та поділ спільного майна подружжя» вказується, що розірвання шлюбу судом за спільною заявою подружжя, яке має дітей (ст. 109 СК України), провадиться в окремому провадженні у випадку, якщо існує взаємна згода подружжя щодо розірвання шлюбу. Під час розгляду справи суд встановлює, чи відповідає заява про розірвання шлюбу дійсній волі дружини та чоловіка, та чи не будуть після розірвання шлюбу порушені їх особисті та майнові права, а також права їхніх дітей [15].

Наприклад, у Постанові Пленуму Верховного суду України від 15 травня 2006 року № 3 «Про застосування судами окремих норм Сімейного кодексу України при розгляді справ щодо батьківства, материнства та стягнення аліментів» в п. 2 ч. 8 йдеться про відкладення розгляду справи або оголошення перерви, якщо відповідач виявить бажання добровільно подати заяву до органу РАЦС про реєстрацію свого батьківства [16].

Тобто в законодавстві переплітаються підстави зупинення провадження у справі і відкладення розгляду справи у справах про розірвання шлюбу та надання строку для примирення подружжя, і вважаємо, що пов'язано це з тим, що до реформування норм цивільно-процесуального законодавства у 2017 році, розірвання шлюбу і надання строку для примирення подружжя було все ж таки підставою для відкладення розгляду справи.

Тому можемо дійти висновку, що законодавцю необхідно належним чином адаптувати законодавство до того, щоб не виникало суперечностей, 


\section{ЮРИАИЧНИЙ ВІСНИК, 2021/5}

колізій та квестій у застосуванні норм цивільно-процесуального законодавства у сфері підстав зупинення провадження у справі чи відкладення розгляду справи у справах про розірвання шлюбу і надання строку для примирення, або все ж таки залишити вказану вище підставу у відкладенні розгляду. Також необхідно законодавчо закріпити і розмежувати поняття зупинення провадження у справі та відкладення розгляду справи у цивільно-процесуальному та господарсько-процесуальному законодавстві, таким чином більш детально регламентувавши ці два інститути.

3 реформуванням українського циивільно-процесуального $i$ господарсько-процесуального законодавства було введено в дію низку новел, у тому числі щодо зупинення провадження у справі про розірвання шлюбу $i$ надання строку для примирення подружжю. У статті розкривається актуальність обраної теми щодо квестій, які виникають за обставин зупинення провадження у справі про розірвання шлюбу й надання строку для примирення подружжю, зроблено аналіз наукових досліджень, охарактеризовано основні публікацій 3 обраної тематики.

Оскільки не кожну справу можна розглянути в одному судовому засіданні та в одному безперервному процесі, то виникає потреба тимчасово зупинити провадження $у$ справі, відкласти розгляд справи або оголосити перерву у судовому засіданні, тому авторами статті з'ясовано на науково-теоретичному рівні поняття таких інститутів ццивільно-процесуального ma господарського-прочесуального законодавства, як відкладення розгляду справи та зупинення провадження у справі. Звертається увага на наявні проблеми в розумінні ц̧их понять.
Cтаття містить обрунтовані, виокремлені спільні та відмінні риси інститутів зупинення провадження у справ та відкладення розгляду справи, які можуть допомогти запобігти розбінностей, колізій щодо розмежування $і$ характеристики ицих двох інститутів $y$ науково-теоретичному розумінні та в застосуванні норм діючого законодавства на практиці. Розглянуто проблеми та особливості застосування норм законодавства під час зупинення провадження $у$ справі про розірвання илюбу та надання строку для примирення подружжю, також зверталася увага на розгляд судами даної категорії справ не тільки в позовному, а й в окремому провадженнях.

Авторами опрацьовано чинні нормативно-правові акти, основними серед яких є Цивільний проиесуальний кодекс України ma Господарський проичесуальний кодекс України. Розглянено судову практику з обраної проблематики: Постанови Пленуму Верховного суду України, ухвали про зупинення провадження у справі про розірвання шлюбу $i$ надання строку для примирення подружжю. Зроблено авторські висновки $і$ пропозиціі внесення відповідних змін до иивільно-процесуального $i$ господарсько-процесуального законодавства, а саме: дефініцій понять зупинення провадження у справі та відкладення розгляду справи, а також щодо уникнення в майбутньому квестій за умови застосування норм законодавства в практичній діяльності, які стосуються зупинення провадження у справі про розірвання шлюбу та надання строку для примирення подружжю.

Ключові слова: зупинення провадження у справі, відкладення розгляду справи, інститути тимчасового припинення розгляду справи, подружжя, сторони, строк, ухвала, судове засідання, цивільно-процесуальне та 
господарсько-процесуальне давство.

Pleva V., Mazur V. Questions for suspension of proceedings in the case of divorce and granting a deadline for reconciliation of spouses

With the reform of the Ukrainian civil procedure and economic procedure legislation, a number of novelties were introduced, including the suspension of divorce proceedings and the granting of a period for reconciliation between spouses. The published article reveals the relevance of the chosen topic on the quests that arise when the proceedings in the case of divorce and the granting of a term for reconciliation of the spouses, analyzes the research, describes the main publications on the chosen topic.

Since not every case can be considered in one court session and in one continuous trial, then there is a need to temporarily suspend the proceedings, postpone the hearing or adjourn the court hearing, so the authors clarified at the scientific and theoretical level the concept of such institutions civilly of procedural and economic-procedural legislation, as a postponement of the case and the suspension of proceedings and draws attention to the existing problems in understanding these concepts.

The article contains substantiated, highlighted common and distinctive features of the institutions of suspension of proceedings and adjournment of cases, which can help prevent differences, conflicts on the distinction and characteristics of these two institutions in scientific and theoretical terms and in the application of current legislation in practice. Problems and peculiarities of application of legal norms at suspension of proceedings on divorce and granting of term for reconciliation by spouses are considered, attention was also paid to consideration by courts of this category of cases not only in claim, but also in separate proceedings.

The authors have developed the current regulations, the main among which are the Civil Procedure Code of Ukraine and the Commercial Procedure Code of Ukraine. Judicial practice on the selected issues, namely the Resolution of the Plenum of the Supreme Court of Ukraine, the decision to suspend the proceedings in the case of divorce and granting a term for reconciliation of spouses is exposed. The author's conclusions and proposals for making appropriate changes to the civil procedure and economic procedure legislation, namely the definitions of the suspension of proceedings and adjournment of the case, as well as to avoid future quests in the application of legislation in practice relating to the suspension of proceedings in the case of divorce and granting a period of reconciliation to the spouses.

Key words: suspension of proceedings, adjournment of proceedings, institutions of temporary suspension of proceedings, spouses, parties, term, decision, court session, civil-procedural and economicprocedural legislation.

\section{Література}

1. Цивільний процесуальний кодекс України: Закон України від 18 березня 2004 р. № 1618-IV. Відомості Верховної Ради України. 2004. № 40-41, 42. Ст. 492.

2. Зейкан Я.П. Коментар Цивільного процесуального кодексу України. 2-ге вид., доп. Київ : Юридична практика, 2007. 592 c.

3. Штефан М.Й. Цивільне процесуальне право України: Академічний курс : підруч. для студ. юрид. спеи. вищ. навч. закл. Київ : Ін Юре, 2005. 624 с.

4. Цивільний процес Украйни: академічний курс : підруч. для студ. юрид. спец.. вищ. навч. закл. / за ред. С.Я. Фурси. Київ : Видавещь Фурса С.Я.: КНТ, 2009. 848 с. (Серія «Проиесуальні науки»).

5. Беляневич B.E. Господарський процесуальний кодекс України: науково-прак- 
тичний коментар. Видання третє. Київ : «Юстініан», 2007. 672 c.

6. Цивільне процесуальне право України : Підручник / С.С. Бичкова та ін.; за заг.ред. С.С. Бичкової. Київ : Атіка, 2009. $760 \mathrm{c}$.

7. Трач О.М. Поняття зупинення провадження у справі в ицивільному процесі. Університетські наукові записки. 2015. № 55. C. 42-50.

8. Тимчасове зупинення судового розглядy. URL: http:/ / mego.info

9. Господарське проиесуальне право України : підручник / В.Д. Чернадчук та ін.; за заг. ред. к.ю.н. В.Д. Чернадчука. Суми : ВТД «Університетська книга», 2006. $331 \mathrm{c}$.

10.Господарський процесуальний кодекс України : Закон України від 6 листопада 1991 р. № 1798-XII. Відомості Верховної Ради України. 1992. № $6 . \mathrm{Cm}$. 56 .

11. Ухвала про зупинення провадження у справі та надання строку для примирення від 5 серпня 2019 р. Справа № 523/7954/19 Провадження № 2/523/3375/19. URL: https: / / zakononline.com.ua/courtdecisions/show/83539939

12. Ухвала про зупинення провадження у справі та надання строку для примирення від 7 жовтня 2019 р. Справа № 477/2148/19 Провад- ження № 2/477/905/19. URL: https: / / zakononline.com.ua/courtdecisions/show/84834323

13. Ухвала про зупинення провадження у справі та надання строку для примирення від 26 травня 2021 р. Справа № 477 / $243 / 21$ Провадження № 2/477/464/21 URL: https: / / verdictum.ligazakon.net / document/97190783.

14. Сімейний кодекс України від 10 січня 2002 р. № 2947-III. Відомості Верховної Ради Украйни. 2002. № 21-22. Cm. 135 .

15. Про практику застосування судами законодавства при розгляді справ про право на шлюб, розірвання шлюбу, визнання його недійсним та поділ спільного майна подружжя : Постанова Пленуму Верховного Суду України від 21 грудня 2007 р. № 11. База даних «Законодавство України». URL: https: / / zakon.rada.gov.ua/laws / show/ v0011700-07\#Text

16. Про застосування судами окремих норм Сімейного кодексу Украйни при розгляді справ щодо батьківства, материнства та стягнення аліментів : Постанова Пленуму Верховного Суду України від 15 травня 2006 р. № 3. База даних «Законодавство України». URL: https: / / zakon.rada.gov.ua/laws / show / v0003700-06\#Text 